SLAC - PUB - 4757

November 1988

$(\mathrm{A} / \mathrm{I})$

SLAC-PUB-- 4757

ERRATA

DE89 002837

\title{
A FASTBUS FLASH ADC SYSTEM \\ FOR THE MARK II VERTEX CHAMBER •
}

\author{
LOY BARKER \\ Stanford Linear Accelerator Center \\ Stanford University, Stanford, Calffornia 94309
}

The Acknowledgements Section of this publication was inadvertently omitted. The following people contributed to this paper: Leo Paffrath, Kenneth G. Hayes and David P. Hutchinson.

Please note that the following corrections are made on page 2, in figure 3:

Analog In (193-278) is changed to Analog In (193-288) and Aralog In (279 -374) is changed to Analog In (289 -384).

- Work supported by the Department of Energy, contract DE-AC03-76SF00515.

Presented at the Nuclear Science Symposium, Orlando Florida, November 9-11, 1988 


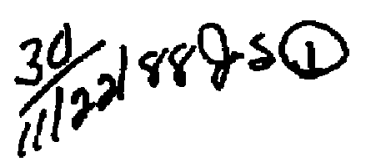

\section{A FASTEUS FLASH ADC SYSTEM FOR THE MARK II YERTEX CHAMBER' \\ LOY BARKER \\ Stantard Linear Accelerator Center Stanford Univerrity, Stanfond, Californis 94309}

\section{INTHODUCION}


Merk II experimeat at the Stanford Lineur Accelaralor Centar


verter chamber where aigalle eould occar ores o reletivaly loat time, epproximutaly 10 mierencosed. Thim las tims, coupled with fant cable amplitere, necentlated an alterante denion approech then we wad with o dE/dX FASTBUS ten ADC



\section{Paystcat condeUtamor}

A ruprenententon of the phyicel contruration of the FAST. BUS portion of the gratem is ahowa in Flpure 3. The aub ortem is contaliad in two FASTaUS erate. Thare ane 20 FADC board in the subsentem, $12+1$ apare in exeb

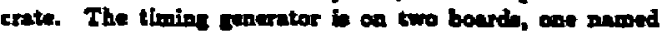
I/O Controller and the other namod I/O Iateriace. All (20) Eigh Spead clock are driven on individual ahiolded tirinted pair eable from the I/O Controlle board. Thi wa doas to

\section{SUBSYSTEMBLCCK DUBANA}

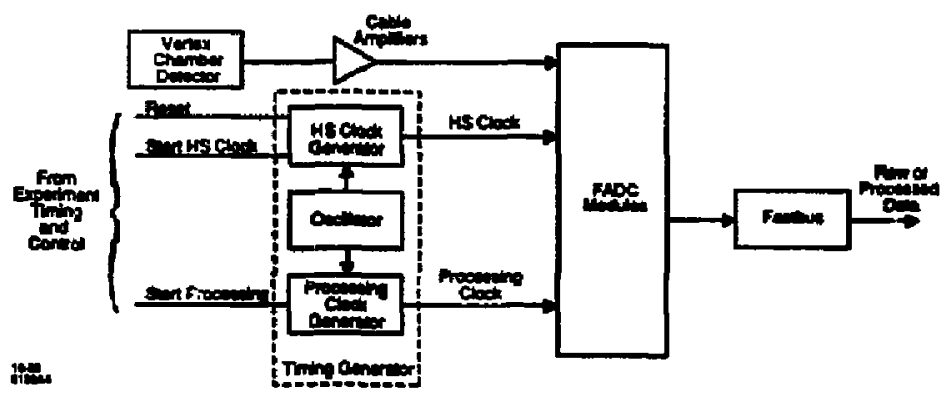

Figure 1.

\section{GHNAn OPFATION}

Approximutaty sto analoc thal froin the Vatex Chember Detcetor are ceat to the Flach Andog-to-Digital (FADC) module vie the Cable Amplifin. The FaDC module dteitive the andos signin into 1002, 10 arroevcond exmple for exch input, with eix bit mplitude reolution. The FADC modulas alo have the capability of detecting when the cmplitude has

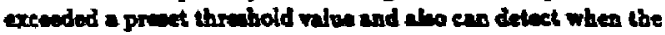
amplitude drope belaw the threhold.

Fisure 2 ahow the overall timing involved in the rytem. The RESET pube elants any eurnent inode and gets the FADC module inte the Aequibition mode. In this mode the gyatem will difitive the anclos bpots with the timing dexived from the Bleh Speod (ES) Clock. The next pule to arive it the START

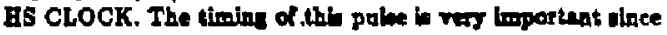
the GS Clock is coberent with this pule and all the liming for dipitination in derived trom thi clock. The nomber of pules in the HS Clock burt is detarmined by the thains smarntor. If further procesine in denired a START PROCSSSING aimal mut oceur before the next RDSET pule arriven. The START PROCDSSWo dignd will tet the FABC module into the Procusins mode, and will allow the Procemine Clock to provide timing for the procening to Hke place. When the procestine cycle in complete the EADC module will drop out of the procewing mode and will be execonith for FUSTBUS operations.

-Work supported by the Department of Eacro, contract DEAcos-70sroosis.

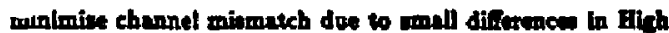
Spend Clock woreohape. Both the I/O Controller and the I/O lpeerfece board drive three dignel on their crate betplenes:

ACQUisITION

START PROC PROCESSING CLK

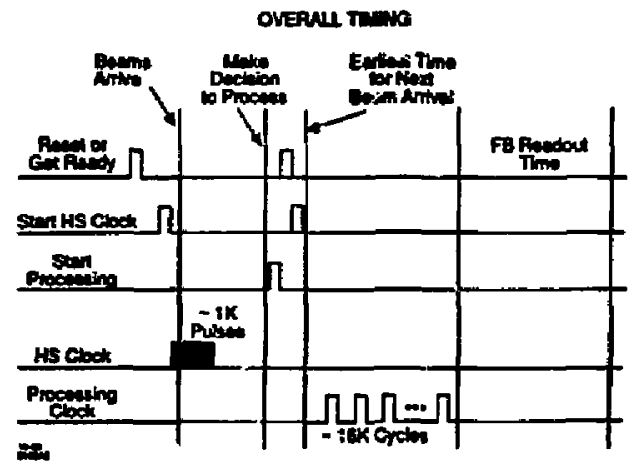

Figure 3.

Prevented at the Nuclear Science Sympasiun, Orlando Florid, November 9-11, 1998 
Prrescul confrediranow

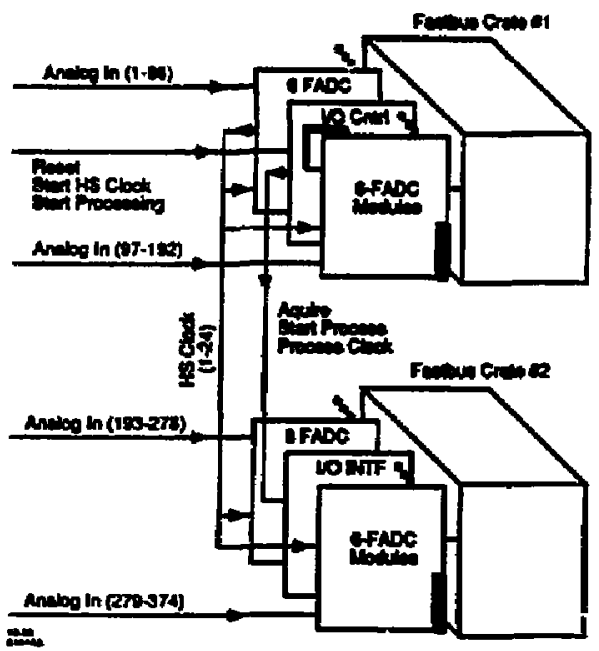

Fisure 3.

The sparen are installed in the crate so that they can be powered-up and calibrated aheed of tim. The on-bonrd oacillator it on the 1/0 Coatroller bourd. The cratu are not full os there is room ho add mose toodule pecmary lo ecem the FASTBUS crale sermants.

\section{OPERATING SPECLICS}

\section{Timine Cerarator}

The timine senerclor dingram in shown in Firure 4 . The on-bourd oucillutar in a commercial device built by Berkaley Nucleonich. Some pertioent apuclientions:

modw . . . . . . . . . . . . . . . . . . c-1000 frequency . . . . . . . . . . . 100 M" Frequency strbitity . . . . . . . . . $+/-2 \times 10^{-7} /$ menk

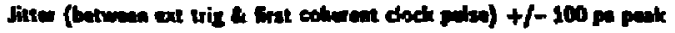
input/outpat lwols . . . . . . . . . . ECL

The timing generator the the expubiluty of generating two timing atringe - Bith Spend Clock and Proemins Clock.

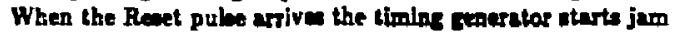
tranferring the acquinition number into the length counter, and ende oue an ACQUISITION puine to the FADC modules. It aleo clearn a Start tribibit letch. When the START HS CLCCK pule arrive, the cocillator aysea of the trail adse of


HS Clock is ment to all the FADC modulo. Aher the cocille. tor moe the Start Inhibit latch is at agis to fobibit multiple aterte. The lent th counter counte down at ach HS Clock pules.
Who tho lagth counter rexches wo the BS Clocks wo gated a.

Whan the START PROCESSING puln arive the timing




all the FADC modnle. The timlas raperator then endo oul - 20 Mhe dignel known an the PROCESSDNG CLK to all the FADC module. The kenth counter in decremented on euch PROCDSS CLOCK and whas it sucher wero the PROCESS ctock ba cated of.

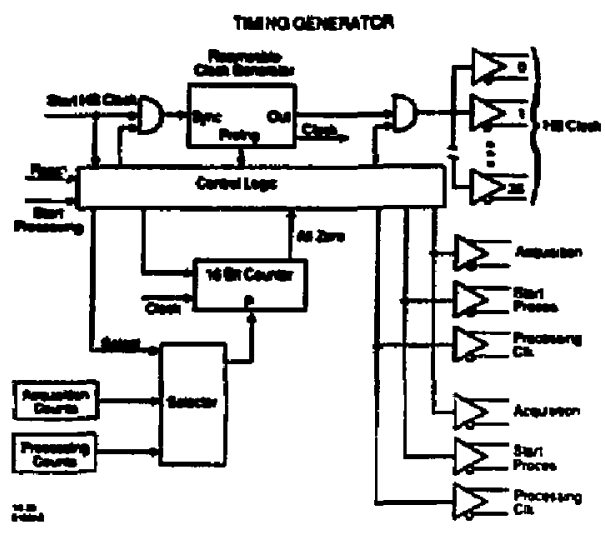

fiqure 1.

\section{FADC Module}

The Flah ADC module bue the following functional cherscterintica:

- 16 Anvlos to difital channob - each channel has:

- An teolaled difierential umplifier

- Two emitter-follower amplifer stages

- Menval d.e. ofinet edjutment

- A Git, $100 \mathrm{Mapa}$, tuht andos-to-digital converter

- Date memory for 1024 (IK), 6 bit, words

- Procemine lopic

- Thromold memory - 16 exch, 4 bit words

- 6 bil comparator

- Addrw memory - 32 each, 10 bil words

- Bolds addreses of firt data over the threshold nue

- Eolde addres of lant date over the threshold rilue

- FASTBUS lojie

- Supporta data space and cer apace partitioning 
- Bw a 14 bit NTA minter - dooble as an eddrow generator durine Aequinition mode and Dete Procening mode

- Sopports rasdom date (mode 0) Reads and Write

- Supports block tramerer (mode 1) Beads and Wrilm

- Supporta NTA tranefor (mode 2) Reado and Write

- Internal menory wecks

Dat Munory . . . . . . . . Read Ody

Thembatd Mumoty . . . . . . Rad/hwito

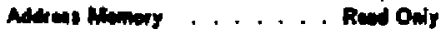

- Retura SS codes oa ell tranefers (Burg code returned If FASTBUS tranter attemptad durins Acquisition bode or Dau Procenine mode

\section{FADC Module Operatlon}

The FADC module block dierram is thown in Pisure 5.

FLASH ADC MCOUE BLOCK DMCRAM



Firure 5

Firac a threahold munt be eatablinhed for each ehannel. This can be any value between 0 and 15 (decimal). Theae values are londed into the Threshold Memory. The module soes into the Acquiailion mode when the $A$ CQUISITION pulse is received. The HS Clock signal provides timing pulses so that

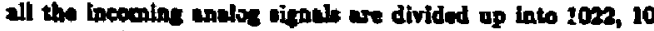


atored th the Dats Memory. Nax, the module rom into the Data Procening mode when the START PROCESS. alond in ancovature. If this mode ench coplitude ralue is compared with its channal's throhold and the "int over" and "lnat over" eddre vive are recorded (in the Addru Memory). Sw Pirare 6. The rate of oparation in controlled by the Procin. Cloct.

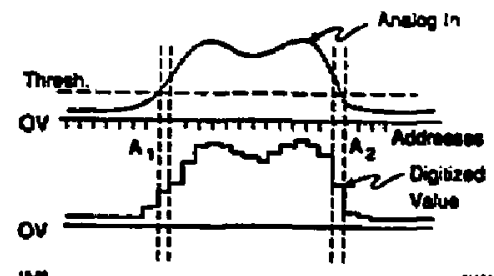

Figure 6.

\section{FasTaUE Operatlone}

Uaully at thi point the hout will Read the Addres Memory and deide which portions of the Date Memory are interating and will read jut thene portion. The amplitude of the dipitied waveform will be proportional to the velocity of the jonisias particle and the timing of the waveform will be proportional to the proximity of the particle to the senting wirta in the chamber.

\section{SYSTBM TEST RESULTS}

The aytern ients to difo hure shown a timing rewolution difme of 200 pitoneconds.

\section{REPERTNCO}

[1] See IEEE Transuction on Nueles Seience $\mathbf{s b}, 1$ (1986) pp. $86-89$.

\section{DISCLAIMER}

This reporn was prepared as an account of work sponsored by an agency of the United Stales Government. Neither the United States Government aor any egency thereof, nor any of theit Governmen. Neither the Unicd Stetes Gor implied, of sesumes any legal linbility or responsiemployes, makes any watrenty. express or implicd, of an informetion, apparatus, product, or

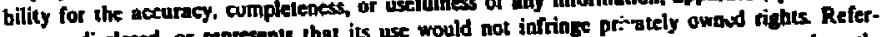
process disclosod, or represents that its use would not infring pre by trade name trademath. ence herein to any specific commercial produch, process, or service by cis endarsement, recommanufacturer. or atherwise does not necessanily constitute or imply is endorsernen, The views mendation, or favoring by the United States Gowefriment or any dise of reflect theac of the and opinions of authars expressed herein do or 